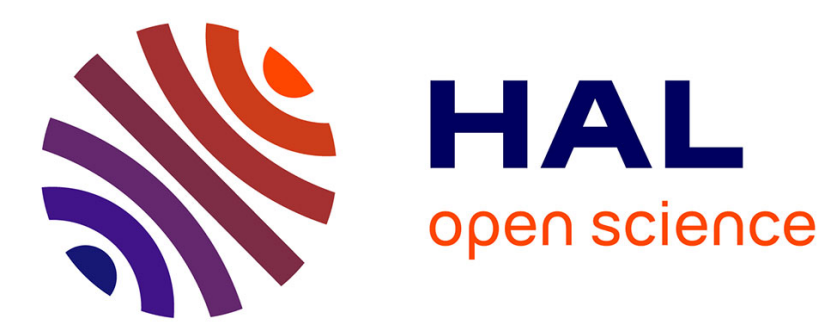

\title{
Water: Human Right or Commodity? Reflections on the Effectiveness of a Human Right to Water \\ Marie Cuq
}

\section{To cite this version:}

Marie Cuq. Water: Human Right or Commodity? Reflections on the Effectiveness of a Human Right to Water. Human Rights Abuses in the Contemporary World: Legal approaches, Sep 2011, Tbilissi, Georgia. hal-00712821

\section{HAL Id: hal-00712821 \\ https://hal.science/hal-00712821}

Submitted on 28 Jun 2012

HAL is a multi-disciplinary open access archive for the deposit and dissemination of scientific research documents, whether they are published or not. The documents may come from teaching and research institutions in France or abroad, or from public or private research centers.
L'archive ouverte pluridisciplinaire HAL, est destinée au dépôt et à la diffusion de documents scientifiques de niveau recherche, publiés ou non, émanant des établissements d'enseignement et de recherche français ou étrangers, des laboratoires publics ou privés. 


\section{Water: Human Right or Commodity? Reflections on the Effectiveness of a Human Right to Water}

Marie Cuq, Ph.D. candidate, UPOND, CEDIN

Before I begin, I would like to thank the organizers of this conference for their support, as well as all the professors and students who are attending this three-day discussion on the conciliation between human rights and the economic globalized economy, a question that is extremely topical. I would also like to thank the organizers for inviting me to participate in this panel, which will allow me to discuss a particular aspect of this conference's topic: the issue of the effectiveness of the human right to water.

To introduce the subject, I will begin by clarifying the contours of this area of law. Water, in the context of human rights, is defined as the "liquid used by man" for his own use, in other words, drinking water: ${ }^{1}$

- We know that water is omnipresent on our planet: $70 \%$ of the Earth's surface is covered by oceans. However, $97 \%$ is actually "saltwater and unfit for direct consumption": ${ }^{2}$ freshwater represents a mere $3 \%$ of the world's water supplies.

- Moreover, freshwater is not always available or accessible to man's needs. For instance, icebergs constitute $70 \%$ of the planet's freshwater supplies ${ }^{3}$ but extraction techniques are currently unable to render that water readily accessible. Thus, available freshwater only represents $0.25 \%$ of the world's entire water supplies. ${ }^{4}$

Accordingly, we can understand the current concern about the decrease of available freshwater throughout the world: water is subject to an increasing demand and a

\footnotetext{
${ }^{1}$ Dictionary Le nouveau Petit Robert, (J. Rey-Debove et A. Rey dir.), Paris, Le Robert, 22 ${ }^{\mathrm{ème}}$ éd., 2009, pp. 799 and 800 see eau.

${ }^{2}$ F. Quilleré-Majzoub, “A qui appartiennent les nuages ? (Essai de définition d'un statut des nuages en droit international public," Annuaire français de droit international, 2004, p. 653.

3 F.Quilleré-Majzoub, "Glaces polaires et iceberg: quid juris gentium ?," Annuaire français de droit international, 2006 p. 433. (Experimenting the towing of icebergs in Arabia, Africa or America)

${ }^{4} \mathrm{~S}$. Paquerot, L'eau douce : la nécessaire refondation du droit international, éd. Sainte-Foy (Québec) : Presses de l'Université de Québec, 2005, p. 2.
} 
diversification of its uses. ${ }^{5}$ Population growth, increased water salinization, water pollution, and weather hazards ${ }^{6}$ make the preservation and sustainable use of water all the more crucial.

In this context, a legal approach is necessary to conciliate the different uses of water and to ensure a universal access to drinking water. As early as the Mar Del Plata Conference in 1977, the Member States of the United Nations asserted that "All peoples, whatever their stage of development and their social and economic conditions, have the right to have access to drinking water in quantities and of a quality equal to their basic needs."7 The willingness to recognize such a right to water was recently reasserted through the adoption on July 28, 2010 by the United Nations General Assembly of a resolution entitled "The human right to water and sanitation." ${ }^{8}$ However, the treaty body of the International Covenant on Economic, Social and Cultural Rights, the Committee on Economic, Social and Cultural Rights, had already started defining the contours of the right to water in its General Comment $\mathrm{n}^{\circ} 15$, on November 2002. The General Comment reads that the right to water is the "sufficient, safe, acceptable, physically accessible and affordable water for personal and domestic uses."9 According to this comment, water must be:

- Available in sufficient quantities and provided in a continuous manner

- Of quality, namely, "safe" water free from substances that constitute a threat to health

- And "accessible without discrimination": especially with regards to geographical proximity but also with regards to "economic" access: water must be " affordable for all."

The Committee on Economic, Social and Cultural Rights not only clarified the contents of the right to water but also set forth the obligations of States with respect to the implementation of that right. Three types of obligations exist:

\footnotetext{
${ }^{5}$ A. Taithe, L'eau. Un bien ? Un droit? Tensions et opportunités, Stratégie et perspective, 2008, pp. 19 to 37. ${ }^{6} \mathrm{M}$. Tignino and D. Yared, "La commercialisation et la privatisation de l'eau dans le cadre de l'organisation mondiale du commerce”, Revue québécoise de droit international, 2006, vol.19 n², p.160.

7 1st Part, Chap. I, Resolution II of the Report of the United Nations Water Conference, Mar del Plata, March 1425, 1977, UN Doc. E/CONF.70/29 ; Reaffirmed in chap. 18 of Agenda 21, action plan accompanying the report of the United Nations Conference on Environment and Development, Rio de Janeiro, June 1-14, 1992, UN Doc. A/CONF.151/26/Rev.1.

${ }^{8}$ United Nations General Assembly Resolution A/RES/64/292, "The human right to water and sanitation," July 28, 2010, available at: http://www.un.org/ (visited on 26/08/2010).

${ }^{9}$ General Comment $n^{\circ} 15$ of the Committee on Economic, Social and Cultural Rights, "The right to water (art. 11 and 12 of the International Covenant on Economic, Social and Cultural Rights)", 29th session, November 29, 2002, UN Doc. E/C.12/2002/11, para. 2.
} 
- An obligation to respect: States must refrain from taking measures that may directly or indirectly interfere with the enjoyment of the right to water.

- An obligation to protect whereby States must prevent any third party, individual, corporation or state entity from interfering with the access to water.

- And an obligation to fulfill, which entails taking positive measures to allow the full enjoyment of the right to water.

- The Committee adds to this list a series of so-called "international" obligations according to which States must take into account the right to water when negotiating future international agreements and refrain from taking measures that would interfere with the enjoyment of that right in other countries.

By precisely stating the obligations of States, this general comment provides us with both a definition of the contours of the right to water and its legal framework.

Therefore, why ask ourselves about an economic designation for water when its legal framework seems on its face to be self-sufficient? Precisely because, even though the Committee's comment contributed to the justiciability of the right to water, the economic significance of water cannot be ignored; and while this economic significance does not call into question the existence of the right to water, it certainly calls into question the effectiveness of its implementation.

Indeed, aside from its legal designation as a human right, water may also be considered as a commodity and therefore be subject to the rules of international economic law, and in particular the rules of international trade law:

- International law on foreign investment is also likely to apply to water and has in fact given rise to several arbitral disputes in that area. Unfortunately, we will not be able to discuss this point at this time and place. ${ }^{10}$

- We will focus exclusively on international trade law, and more specifically on the norms of the World Trade Organization that relate to goods, as set forth by the Marrakech Agreement of 1994. The purpose of the General Agreement on Tariffs

\footnotetext{
${ }^{10}$ States are generally bound by four main principles: the obligation to provide a fair and equitable treatment to foreign investors, the obligation to refrain from discrimination (the principle of national treatment and the most favored nation principle), the obligation to respect several conditions in direct and indirect expropriation,_and the prohibition of "prescriptions de performance."
} 
and Trade $(\mathrm{GATT})^{11}$ is the liberalization of international trade through the lowering or suppression of quotas and tariff barriers.

Having said this, it is interesting to assess the extent to which international economic law may apply to water, when water is already subject to the legal framework of human rights. If water may be designated as both a human right and a commodity, what consequences will that entail for the effectiveness of the human right to water? In other words, to what extent may we consider international economic law as an obstacle to the effectiveness of the right to water? On the other hand, could international economic law also be a means to fulfill that right?

In order to obtain some answers, we will first address the issue of the applicability of international trade law to water and explain how its system of exceptions/derogations fails to sufficiently integrate human rights. As a result, we will find that international trade law appears to hinder the effectiveness of the right to water. Then, we will balance this finding by explaining how international trade law may also be a vector towards the effectiveness of the right to water, as recognized by international human rights law.

\section{I- The applicability of international economic law, an obstacle to the effectiveness of a human right to water?}

A) Whether water comes within the material scope of international economic law norms.

While this question has been answered in the field of international law on foreign investment, ${ }^{12}$ it remains highly debated in international trade law; however, water is not by principle excluded from international trade law norms.

Water comes within the material scope of the GATT as long as it can be qualified as a good or a product, within the meaning of article I, III and XI of the Agreement. According to legal theory, two conditions must be met for water to qualify as a good or product: water must

\footnotetext{
${ }^{11}$ General Agreement on Tariffs and Trade, Annex 1A of the Marrakech Agreement establishing the World Trade Organization, April 15, 1994, 1869 United Nations Treaty Collection, 426.

${ }^{12}$ The multitude of disputes involving the application of foreign investment law to water services is proof of the applicability of its norms (see notably the cases brought before ICSID : Aguas del Tunari contre Bolivie (2002, $\left.\mathrm{n}^{\circ} \mathrm{ARB} / 02 / 3\right)$; Suez \& Vivendi Universal v. Argentine $\left.\mathrm{n}^{\circ} \mathrm{ARB} / 03 / 19\right)$; Aguas de Santa Fe Suez, Aguas de Barcelona and Interaguas Servicios Integrales del Agua v. Argentine (ARB/03/17, decisión July 30, 2010) ; Biwater Gauff v. Tanzania, (n ARB/05/22, Award of July 24, 2008)
} 
have a commercial value and must be rendered fit for commercialization by some man-made process. $^{13}$ :

○ As regards the second condition, "man-made process", one may assert:

- That it is easy to consider bottled drinking water as a product. After transformative processes such as extraction, gasification, or packaging, water is offered to the public in a commercial form.

- The question is more complex when it comes to the transportation of water in large quantities via pipelines or in plastic bags, or even through the deviation of watercourses. The degree of "human intervention" is thus difficult to assess and only excludes water in its natural state, exempt from human intervention.

- The market price of water is equally difficult to assess since it is hard to determine whether the price paid for water corresponds to the services related to water (transportation, sanitation, treatment) or to the water itself. Multinational corporations tend to publicly deny the commercial designation of water, refusing to charge water as a commodity. ${ }^{14}$ However, several international declarations have stated otherwise and consider that "managing water as an economic good is an important way of achieving efficient and equitable use, and of encouraging conservation and protection of water resources"15 (Dublin Statement, 1992).

$\underline{\boldsymbol{B}})$ Therefore, if water may qualify as a commodity, it can be subject to the norms of the WTO.

In this context, States must apply the GATT disciplines:

- They must eliminate all quantitative restrictions on the exportation or importation of water. $^{16}$

O In addition, according to the most favored nation and national treatment principles, States may not treat imported water less favorably than national water nor discriminate among water imported from different countries. ${ }^{17}$

\footnotetext{
${ }^{13}$ M. Tignino and D. Yared, "La commercialisation et la privatisation de l'eau dans le cadre de l'organisation mondiale du commerce," Revue québécoise de droit international, 2006, vol.19 n², p.170.

${ }^{14}$ Suez/Ondeo, "La vrai bataille de l'eau", Nov. 2001, p. 6, cited in M. Cossy, op.cit., p. 177.

${ }^{15}$ Principle 4 of the Dublin Statement, supra.; Idem Para. 18 of Agenda 21, supra.

${ }^{16}$ Article XI, General Agreement on Tariffs and Trade, supra.

${ }^{17}$ Articles I and III, General Agreement on Tariffs and Trade, supra.
} 
However, the underlying dynamic of the WTO agreements seems to merely focus on the liberalization of the trade of water in a manner that does not sufficiently take into account the right to water. And yet, there can sometimes be contradictions: for instance, setting a market price on water may interfere with the basic human needs of the most destitute and therefore interfere with their right to water.

While it is true that the law of the WTO provides exceptions and restrictions to the application of its rules, they are often perceived as insufficient in terms of integrating the noneconomic aspects of water.

o First, it should be noted that there is no general exception relating to human rights in the GATT agreement. Thus, a State cannot base its legislation on such an exception to limit the application of WTO norms and ensure an effective protection of the right to water.

- Other exceptions provided in the agreement may indirectly deal with the issue of the right to have access to water. For example, States are entitled to adopt national measures to "prevent critical shortages of foodstuffs" 18 or measures "necessary to protect human health or life."19 These exceptions could cover the humanitarian or sanitary aspects of the access to water, but it should be noted that these exceptions are strictly construed:

- First, a State can only adopt temporary measures, thus preventing the implementation of any long-term national policy that would promote the right to water.

- Moreover, any measure adopted must be necessary and proportionate to the purpose sought, that is, either the people's health or food shortage. The WTO Dispute Settlement Body adopted a strict interpretation of these standards in its case law.

- Finally, national measures must not "constitute a means of arbitrary discrimination between countries or a disguised restriction on international trade." 20

Therefore, since these conditions are cumulative, this scheme of derogations and exceptions leaves little space to the requirements of the right to water. Nevertheless, when water is defined as a commodity, it automatically falls within the material scope of the

\footnotetext{
${ }^{18}$ Article XI, para. 2 al. a) General Agreement on Tariffs and Trade, Annex 1A of the Marrakech Agreement establishing the World Trade Organization, April 15, 1994, 1869 United Nations Treaty Collection, 426.

${ }^{19}$ Article XX par. b), General Agreement on Tariffs and Trade, supra.

${ }^{20}$ Preamble of Article XX, General Agreement on Tariffs and Trade, supra.
} 
Human Rights Abuses in the Contemporary World: Legal approaches 6. - 9. September 2011

Human Rights and a Globalized Economy - Areas of conflict? Friday 09.09.2011

WTO's normative dynamics of economic liberalization. In this context, some scholars adopt the view that the "commoditization" of water impinges on the effectiveness of a human right to water.

But should we stop our reasoning at this point and only consider the application of WTO norms as an obstacle to an effective right to water? I think not, because even though WTO norms do not aim directly at the implementation of the right to water, this area of law should not ignore, nor be ignored by the issue of the effectiveness of the right to water.

\section{II- Taking into account the application of international economic law to water, a vector towards the effectiveness of the right to water.}

Merely acknowledging the applicability of WTO law to water may be a starting point in the search of a more effective right to water. Indeed, an increased mutual recognition of international human rights law and WTO law could lead to a better effectiveness of the right to water. In concrete terms, two main trends should be explored: a better integration of the requirement of the right to water within international trade law (A) and an increased recognition of the economic value of water within international human rights law (B).

A) A better integration of the requirements of the right to water within international trade law.

Currently, WTO law only sets forth a system of derogations from the application of its rules for reasons of national general interest. For instance, the WTO will only consider food shortages and environmental concerns if States qualify them as national general interests and if they request a derogation.

The right to water would be better served if national interests were more frequently taken into account through a broader definition of some exceptions:

- Thus, as previously mentioned, the GATT agreement could provide for a general exception that would ensure the effectiveness of human rights.

- Similarly, current exceptions could be interpreted more liberally to enable States to implement long-term policies for water management.

- During the Doha negotiations, some States had suggested to relax the WTO exceptions ; however, these proposals were more concerned with protecting States' sovereignty over 
their water resources. ${ }^{21}$ Nevertheless, this requirement may contribute to the effectiveness of the right to water in the sense that it would provide States with more flexibility in managing their water resources.

Then why haven't any changes taken place yet when States regularly express their willingness to promote a right to water? Two reasons may explain this, both of which are based on the nature of the international community:

- First, WTO law is a consensual body of norms: the Organization is based on the principle of interstate cooperation since any modification of its norms requires the agreement of all Member States. The World Trade Organization, as opposed to the European Union for instance, cannot adopt secondary legislation, which allows a more flexible evolution of the legal framework. Decisions are made by a majority vote of Member States, but in practice a consensus is almost always sought. Reaching such a consensus may prevent fast evolutions.

- Additionally, the WTO is limited in scope by the principle of specialty that governs every international organization. The Organization's objective is to "supervise the Marrakech agreement, the purpose of which is to promote free trade"22 rather than promoting non-economic considerations. The WTO bodies have had the opportunity to reassert this principle, especially with regards to the protection of the environment. ${ }^{23}$ This also explains why the Dispute Settlement Body is reluctant to adopt a flexible position on this issue.

Consequently, better integrating the requirements of the right to water within the WTO system is not impossible and different ways to accomplish this may be used, but they are dependent on States' will.

$\underline{\boldsymbol{B}}$ Let us now consider international human rights law. How does it take into account the economic value of water in the pursuit of an effective right to water?

\footnotetext{
${ }^{21}$ Debate in the WTO Committee on Specific Commitments: S/CSC/M/17 et S/CSS/M/18/Rev.1, November 20, 2000, Communications of Australia, the European Communities, the United States of America, Japan, New Zealand, Taiwan, Penghu, Kinmen et Matsu in the WTO Committee on Trade and Environment, OMC Doc. $\mathrm{TN} / \mathrm{W} / 28(2005)$.

${ }^{22}$ M.P. Lanfranchi, op.cit., p. 293.

${ }^{23}$ Report by the WTO Secretariat, Trade and Environment in the WTO, Genève, OMC, 2004, p. 7, available online at: http://www.wto.org (26/08/2010).
} 
- The answer to this question is two-sided: while the Committee on Economic, Social and Cultural Rights has considered the price of water as an important issue in the fulfillment of the right to water, it merely touched upon other related issues:

- $\quad$ First, the issue of the price of water: as we mentioned previously, the Committee, in its General Comment $n^{\circ} 15$, does not suggest that water should be free but rather that it should be "affordable for all."

The Committee seems to be integrating the economic significance of water because if the services related to water were free, States would be practically unable to delegate water distribution or sanitation to the private sector. In addition, some States are unable to provide these services themselves and have to rely on private enterprises to manage these water services.

The wording "a price affordable for all" raises a number of questions. The Committee's proposal consists of setting water prices based on social criteria and supported by state subsidies. However, some scholars believe that this scheme cannot be implemented in all States, especially not in developing countries, as they do not possess the financial resources necessary to provide such financial support.

Even if the debate on this issue is ongoing, the Committee has the merit of raising the issue, as it did when it addressed the role of the State in situations where water-related services are delegated to the private sector, thus contributing to the pursuit of an effective right to water.

However, General Comment ${ }^{\circ} 15$ fails to address a closely related issue: the possibility for a State to buy water in order to provide its people with an access to water. And yet, the applicability of WTO law leads us to ask whether States facing water shortages may import water to satisfy their people's needs? "Can they rely on international trade law to obtain the water they need?" 24 In this context, buying water could be seen as a means to implement a right to water, since WTO law forbids all restrictions on exportation, to the benefit of States that import water.

\footnotetext{
${ }^{24}$ M. Cossy, "Le statut de l'eau en droit international économique. Principaux aspects au regard des règles de l'Organisation mondiale du commerce", in Les ressources en eau et le droit international, (L. Boisson de Chazournes et S. Salman dir.), Hague Academy of International Law, Nijhoff, Leiden/Boston, 2005, p. 172.
} 
Thus, international human rights law takes into account some dimensions of the economic context in which the right of water operates, even if some other aspects are not yet contemplated as potential means of fulfilling the right to water.

\section{Conclusion}

This was a succinct overview of how international human rights law and WTO law interact in the pursuit of the effectiveness of a human right to water. We may conclude by adding that several international initiatives, such as the Doha negotiation cycle or the UN Millennium Development Goals, contribute to the evolution and improvement of these reflections, which ultimately concern the pursuit of consistency among the various areas of international law.

Thank you for your attention. 